\title{
Strategic Renewal, Cooperation, and Performance: A Contingency Approach
}

\author{
Francisco J. Sáez-Martínez (Corresponding author) \\ Faculty of Economics, University of Castilla-La Mancha \\ Pza. Universidad 2, 02071 Albacete, Spain \\ Tel: +34-902-204-100ｅmail: Francisco.saez@uclm.es \\ Ángela González-Moreno \\ Faculty of Economics, University of Castilla-La Mancha \\ Pza. Universidad 2, 02071 Albacete, Spain \\ Tel: +34-902-204-100ｅmail: Angela.gonzalez@uclm.es
}

Received: September 15, 2011

doi:10.5430/jms.v2n4p43
Accepted: October 13, $2011 \quad$ Published: December 15, 2011

URL: http://dx.doi.org/10.5430/jms.v2n4p43

\begin{abstract}
In this paper, we analyse the influence of cooperation and strategic renewal activities on firm performance. Previous studies on the relationship between strategic renewal and performance are inconclusive. Thus, to cope with this controversy, we follow a contingency approach and, using a large sample of firms, investigate how cooperation and the degree of technological intensity of the environment moderate the relationship between strategic renewal and performance. The results of our empirical analysis suggest that strategic renewal activities are less fruitful in low-technology-intensive sectors when firms cooperate with other entities for such purposes.
\end{abstract}

Keywords: Strategic Renewal, Cooperation, Performance, Contingency Approach

\section{Introduction}

Entrepreneurship research has primarily been concerned with the start-up of new firms. Entrepreneurship has traditionally been viewed as individual-level activities related to creating new organizations, though it has also become accepted as a firm-level phenomenon. Entrepreneurial activities are the outcomes of the interactions between individuals and groups at multiple levels within the firm. Sharma and Chrisman (1999) differentiate between entrepreneurial activities as activities pursued independently and those pursued within the context of the organization. The former are called "independent entrepreneurship", and the latter are referred to as "corporate entrepreneurship" (CE). The notion of CE extends the idea of being bold, proactive, and aggressive towards established firms and is defined as "the sum of a company’s innovation, renewal and venturing efforts” (Zahra, 1995, p. 227). Recently, Kreisser, Marino, Davis, Tang \& Lee (2010) explore the fundamental dimensions underlying corporate entrepreneurship proposing a hierarchical relationship between these various elements. Their empirical findings suggest that proactiveness positively impacts firm's perceptions of opportunities, and firms utilize innovation and strategic renewal in an effort to capture these perceived opportunities.

Innovation is considered the most common and important aspect of CE (Covin \& Miles, 1999) and, as such, has received a great amount of attention in the literature. In contrast, entrepreneurship literature has shown much less interest in renewal than venturing and innovation activities. Strategic renewal has strategic and organizational change connotations and involves re-definition of the business concept, reorganization, and the introduction of system wide changes for innovation (Zahra, 1993). It refers to firm efforts that result in significant changes to the organization's business or corporate-level strategy or structure.

These activities have a high degree of risk, and firms try to improve their chances of success through various approaches. One example is to form alliances to carry out joint research (Hagedoorn, 1993). In alliances, firms can share costs and risks, as well as achieve economies of scale (Deeds \& Hill, 1996). There is a trend towards increasing inter-firm cooperation. That is, inter-firm collaboration for innovation and renewal is a common strategy that firms adopt, 
especially to develop new products and services and/or new processes. Renewal and cooperation activities seem closely related, as both aim to achieve flexibility. Renewal activities may significantly benefit from cooperation, though such benefits have not been sufficiently examined in the literature (Teng, 2007). Researchers have mainly focused on the relationship of networks, strategic alliances, and other forms of cooperation with the development of new business venturing, products, processes, and technologies. Literature has largely neglected the relationship between cooperation and the strategic renewal aspect of CE. Cooperation with other firms to enhance old and new administrative techniques, as well as changes in strategy, organization, and managing competitors, has received much less research interest than technological forms of innovation.

Both the popular press and most academic literature claim that entrepreneurial activities are inherently linked to superior firm performance (Zahra, Jennings, \& Kuratko, 1999). Prior research has proposed that strategic renewal is related to organizational growth and profitability (Covin \& Miles, 1999; Zahra, 1993), though Hart (1992) argues that entrepreneurial strategy making is more likely to be associated with low performance. Moreover, empirical studies are inconclusive. Antoncic (2006) found a direct and negative effect of strategic renewal on performance, whereas Wiklund (1999) found a positive relationship. In addressing this debate, Dess, Lumpkin, and Covin (1997) suggest that studies on $\mathrm{CE}$ and performance should explore this relationship from a contingency or configurational approach. They propose that CE might have a stronger association with performance when combined with the appropriate strategic decisions and environmental conditions. They further emphasize the importance of fit in the CE process as a condition for enhanced performance.

Internally, with regard to decisions, a remaining question is whether cooperation is a useful strategy that increases performance when combined with strategic renewal. That is, do the expected positive effects of strategic renewal increase when the firm cooperates for these purposes? Regarding external environmental conditions, we focus on the effect of the technological intensity of the industry in which the firm operates. Bamberger (2008) calls for researchers to go beyond contextualization of studies and include context in their theories. Therefore, this paper follows this call and strives to analyze the environment as a moderator of the strategic renewal-performance relationship.

The objective of this paper is to fill this gap in the literature. Following Dess et al.'s (1997) and Bamberger's (2008) recommendations, we attempt to explain previous inconclusive results using a contingency approach. Our research contributes to the literature in two ways. First, because of the lack of research on cooperation and strategic renewal activities, this paper contributes to the development of this important stream of research. Second, as mentioned, previous studies on the relationship between strategic renewal and performance are inconclusive. To cope with this controversy, we follow a contingency approach (see Figure 1) and, using a large sample of firms, investigate how cooperation and the degree of technological intensity of the environment moderate the relationship between strategic renewal and performance.

\section{$<$ Figure 1 about here $>$}

The paper is organised as follows: In section 2, we expose the theoretical framework and present the hypotheses to be contrasted. Section 3 briefly describes the data and the research method. The methodologies used include factor analyses and moderated hierarchical regression. Section 4 presents the results of our empirical analysis, and section 5 concludes with a discussion of the results and directions for further research.

\section{Theoretical Framework and Hypotheses}

\subsection{Strategic Renewal and Performance}

Corporate entrepreneurship literature distinguishes between two main types of entrepreneurial activities: corporate venturing and strategic renewal (Verbeke, Chrisman, \& Yuan, 2007). Strategic renewal is a firm's transformation in terms of changing its scope of business or strategic approach (Zahra, 1996); it is broadly defined as the "transformation of organizations through renewal of the key ideas on which they are built” (Guth \& Ginsberg, 1990 p. 5). More restrictively, Covin and Miles (1999, p. 52) define strategic renewal as "the [CE] phenomenon whereby the organization seeks to redefine its relationship with its markets or industry competitors by fundamentally altering how it competes”. They distinguish between strategic renewal and organizational rejuvenation, in that with the latter, the firm seeks to improve its competitive standing by altering its processes and structures. In this paper, following Guth and Ginsberg (1990), we use the broad definition of strategic renewal and refer to the entrepreneurial phenomena that entail strategy and/or organizational changes. We focus on both the organization per se and the strategy that mediates the organization-environment interface. Strategic renewal can involve a reformulation of the firm's corporate strategy, a re-organization of structures, and other system wide changes (Zahra, 1993). Previous research has labelled this phenomenon corporate rejuvenation (Stopford \& Baden-Fuller, 1990) and corporate renewal (Beer, Eisenstat, \& Spector, 
1990). Therefore, strategic renewal, as we consider it, can occur both when the firm develops a "new" strategy and when it tries to increase or sustain competitiveness through the improved execution of a particular "pre-existing" strategy. Both cases may imply a change in the firm's internal processes, structures, and/or capabilities.

According to previous research, strategic renewal, as part of CE, is related to organizational performance, growth, and profitability (Covin \& Miles, 1999; Lee, Lee, \& Pennings, 2001; Zahra, 1993). Empirically, using data from small firms in Sweden, Wiklund (1999) found that the association between entrepreneurial orientation (e.g., strategic renewal) and performance was significant and even increased over time. The thrust of the argument for a positive relationship between strategic renewal and performance is related to first-mover advantages (Liberman \& Montgomery, 1988) and the tendency of firms to take advantage of emerging opportunities implied by CE. Innovation and renewal enable firms to keep ahead of their competitors, gaining a competitive advantage that leads to superior performance. Firms can obtain first-mover advantages by acting earlier than their competitors. These benefits can take the form of economies of scale, switching costs, limited demand and supply, and so forth (Liberman \& Montgomery, 1988). Renewal actions, such as entering new markets, developing new technologies, starting new marketing campaigns, and launching new products/services, often create first-mover advantages. As such, these initiatives often lead to advantageous positions that are difficult and costly for competitors to replicate (i.e., ex post limits to competition).

As we mentioned previously, there is a strong normative bias towards the inherent value of entrepreneurial behaviour and strategic renewal (Covin \& Miles, 1999). However, Hart (1992) argues that entrepreneurial strategy is more likely to be associated with low performance. Lower-performing firms are in greater need of renewal to survive. Empirically, Antoncic (2006) found a direct and negative effect of strategic renewal on performance in his research on Slovenian firms. Previous contradictory empirical results suggest the adoption of a contingency approach to explore the relationship between strategic renewal and performance. The contingency approach suggests that two or more predictor (independent) variables have interactive effects on the value of the criterion variable (dependent). As Arnold (1982, p. 143) notes, “'Contingency' theories, by definition, hypothesize that the relationship between two variables is 'contingent' upon some third variable, and as a result researchers have been concerned with the issue of whether 'moderator' variables 'interact' with independent variables in some predictable manner”. In this paper, we follow the same approach and examine how cooperation and the degree of technological intensity of the environment moderate the relationship between strategic renewal and performance. A similar approach is recently used by Kwee, Bosch \& Volverda (2011) to investigate how top manager's corporate governance orientation influences a firm’s strategic renewal trajectories over time.

\subsection{Cooperation as a Moderator of the Strategic Renewal-Performance Relationship}

Strategic renewal implies "the creation of new wealth through new combination of resources" (Guth \& Ginsberg, 1990 , p. 6). To redefine or establish a re-combination of existing resources towards a new approach for doing business, the firm usually needs to introduce new elements into its resource profile (Floyd \& Lane, 2000). To develop a new corporate image, firms may need tangible resources. Moreover, to formulate a restructuring strategy, they may require intangible resources, such as knowledge. Cooperation may be a key factor in obtaining such necessary resources for strategic renewal.

Literature on cooperation has mainly focused on the analysis of research-and-development (R\&D) activities (e.g., Bayona, García-Marco, \& Huerta, 2001; Veugelers \& Cassiman, 2005) and on how cooperation helps partners achieve better performance. However, empirical evidence of this relationship has been limited (Smith, Carroll, \& Ashford, 1995), and few studies have shown substantial performance improvement through cooperation (Hagedoorn \& Schakenraad, 1994).

Inter-organisational cooperation refers to the joint knowledge-generating process between partners (Chang, 2003). It can provide firms with access to information, resources, markets, and technologies (Gulati, Nohria, \& Zaheer, 2000) and offer them the opportunity to learn new skills (Hitt, Ireland, \& Lee, 2000). Cooperation can even confer credibility and legitimacy to firms (Cooper, 2002). These cooperative arrangements allow firms to gain resources temporarily from others for their own benefit (Grant \& Baden-Fuller, 2004), generate technologies for new business (Inkpen, 2000), and set a technological foundation for change and strategic renewal. Cooperation also provides firms with a channel for learning through access to routines, institutional arrangements, and cultures (Mody, 1993). Firms involved in cooperative ventures also benefit from the reductions in risk (Van Driel, 1992) and the sharing of costs associated with new product/process development and with other non-technological innovations, such as strategic renewal (Deeds \& Hill, 1996).

In many industries, new technologies have the potential to change the way business is conducted. An example is the effect of the Internet on the retail industry. Thus, when cooperation and R\&D alliances lead to major innovations, they 
may also set the foundation for strategic renewal (Teng, 2007). Zahra et al. (1999) propose that cooperation is valuable for strategic renewal. A firm may learn about a new way of doing business from its partner and thus achieve strategic renewal. Moreover, firms can employ cooperation as an intermediate approach to restructuring (Hagedoorn \& Sadowski, 1999). For example, through ownership transfer in a joint venture, a firm may acquire resources to realign its existing business. Firms can also use joint ventures as experiments for strategic renewal efforts.

Cooperation is also an effective approach in pursuing first-mover advantage in strategic renewal efforts (Yoshino \& Rangan, 1995). Because alliances can be quickly forged, they may execute renewal activities swiftly enough to obtain an advantageous position ahead of competitors. If firms implementing strategic renewal focus their cooperative efforts on areas with strong potential first-mover benefits, competitive advantages will emerge (Teng, 2007). Furthermore, when the goal of renewal efforts is to set an industry standard, cooperation becomes even more important (Teng \& Cummings, 2002). Strategic renewal will be more successful when cooperation helps spread the new technology and enhances its acceptability in the industry. Therefore, there are several arguments to propose the moderating effect of cooperation on the strategic renewal-performance relationship. We postulate the following:

$\mathrm{H}_{1}$ : Cooperation positively moderates the relationship between strategic renewal and performance.

\subsection{Environment as a Moderator of the Strategic Renewal-Performance Relationship}

Companies innovate and enter ventures in anticipation of, or response to, their environment. The environment poses challenges and offers new chances to which organizations must respond creatively through entrepreneurial activities (Zahra, 1993). The environment also serves as a source of ideas for innovations, and suppliers, competitors, and customers all provide incentives for firm's innovations, renewal, and venturing. In addition, firms in turbulent environments tend to be more innovative and proactive than firms in stable environments (Naman \& Slevin, 1993).

Some conceptual arguments suggest that entrepreneurial activity is not equally suitable in all environments. As an example, Kim and Pennings (2009) have empirically examined the relationship between strategic renewal and innovations performance in a mature market. Therefore, to analyse the environment's interactive effects, as Bamberger (2008) suggests, we go beyond contextualization of research and include context in theory creation. Traditionally, contextualization has meant introducing variables in a post hoc and merely speculative exercise. However, knowing how environmental and boundary conditions directly affect the phenomena of interest is our goal with a configurational approach. Covin and Slevin (1991) argue that a firm's entrepreneurial posture is more positively related to firm performance among firms in dynamic environments than among firms in stable environments. Dynamic environments encourage entrepreneurial behaviour (Miller, Droge, \& Toulouse, 1988), and organizations often respond to challenging environments, such as dynamic environments, by taking risks, innovating, and exhibiting proactive behaviours (Khandwalla, 1987). According to Miller and Friesen (1982, p. 6), “entrepreneurial firms are often found in dynamic environments.... Such firms may even be partly responsible for making the environment dynamic.... Because innovation prompts imitation, the more innovative the firms, the more dynamic their environments can become”. Moreover, successful innovations often change the relative positions of the firms competing in an industry and reshape its competitive landscape (Kim \& Pennings, 2009). These arguments suggest a bi-directional relationship between environmental conditions and strategic renewal and other CE activities, which makes them a necessary condition to survive in dynamic environments. There are several sources of environmental dynamism, one of which is technological intensity (Sarkar, Echambadi, \& Harrison, 2001). Sectors with high technological opportunity are associated with high-technology activities, and firms in these sectors should be more frequent innovators than those in low-technology activities. Firms in technology-intensive environments, such as computer software, must continually innovate and self-renew to remain competitive. In such environments, strategic renewal becomes a necessary condition to survive. From these arguments, we postulate the following:

$\mathrm{H}_{2}$ : Technological intensity of the environment positively moderates the relationship between strategic renewal and performance.

\section{Research Method}

\subsection{Sample and Measures}

To test our hypothesis, we drew information on the firms' strategic renewal and cooperation activities from the Third Community Innovation Survey (CIS3) conducted by the Spanish Statistical Institute. We obtained information on the firms' strategic renewal, performance, and cooperation activities during the 1998-2000 period. In this database, the unit of analysis is the firm, and the sample covers both manufacturing and services and excludes firms with fewer than 10 employees. We selected both firms that had carried out innovation activities during the study period and firms with innovation activities not completed or abandoned during that period. Our final sample consisted of 11778 firms(Note 1). 


\subsubsection{Strategic Renewal}

Prior research has operationalized strategic renewal in several ways. Zahra (1993) includes three components of strategic renewal activities - namely, mission reformulation, reorganization, and system wide changes-and uses a Likert-type scale to measure them. Though not reported, Antoncic (2006) uses a similar scale to measure strategic renewal. We also use a Likert-type scale (four items) to measure the implementation of new or significantly changed corporate strategies, organizational structures, marketing strategies, and management techniques.

\subsubsection{Cooperation}

The CIS3 survey explicitly defines cooperation as "active participation in joint innovation projects (including R\&D) with other organisations. It does not necessarily imply that either partner derives immediate commercial benefit from the venture. Pure contracting out of work, where there is no active collaboration, is not defined as co-operation in this survey". We used eight measures of the importance of the firm's cooperation in entrepreneurial activities with clients, suppliers, research centres, and other agents in a Likert scale (see Table 1)(Note 2).

$<$ Table 1 about here>

\subsubsection{Environment’s Technological Intensity}

Prior research has operationalized the environment's technological intensity using a dummy variable. We divided the sample into two groups (high- and low- and medium-technology-intensive sectors) following the OECD (2005) classification of technology-intensive sectors.

\subsubsection{Size}

We also included size in our analyses. We measured size as the log of the number of employees.

\subsubsection{Performance}

Finally, we measured performance with six variables that reflect the impact of innovation activities of the enterprise during the 1998-2000 period. We measured variables with a Likert scale that indicated whether innovation improved the quality of products and services or reduced labour costs, among others (see Table 1).

\subsection{Methods}

To analyse the reliability of our measures, we calculated Cronbach's alpha. In addition, we performed an exploratory factor analysis with varimax rotation to identify the possible underlying dimensions of performance, strategic renewal, and cooperation activities. These factor scores were used in the second phase of our empirical analysis. To test the effect of strategic renewal and cooperation on performance, we used a moderated hierarchical regression analysis approach (Neter, Kunter, Nachtsheim, \& Wasserman, 1996).

To test the interaction effects, we produced two interaction terms and added them to the model. We introduced all interaction variables in a single model, as our sample size is large enough to allow the operation. We added the interactions simultaneously, thus controlling for possible multicollinearity among the variables. The computed variance inflation factors ranged from 1.047 to 2.010 in the whole model, which is substantially lower than the value of 10 that Neter et al. (1996) specify as an indication of potential problems of multicollinearity.

\section{Results}

\subsection{Reliability Analysis}

Table 1 shows the reliability analysis of our measures. Cronbach’s alpha for the items establishes an acceptable level of reliability for our scales. In the exploratory factor analysis, we calculated separate factor analyses for each dimension: strategic renewal, cooperation, and performance. As Table 1 shows, all factor analyses yielded a single factor solution, with an eigenvalue greater than 1.

Our measure of strategic renewal includes the implementation of new or significantly changed corporate strategies, organizational structures, marketing concepts/strategies, and the implementation of advanced management techniques or concepts. As we mentioned previously, strategic renewal is one of the CE dimensions identified in the literature, and it refers to a firm's efforts to significantly change its business or corporate-level strategy or structure.

\subsection{Regression}

We employed a moderated hierarchical regression analysis to test our hypotheses. First, we introduced environment, strategic renewal, and cooperation into the model to measure direct effects. Size may also affect the complexity of CE and cooperation activities. Thus, to investigate potential confounding due to the possible influence of size, following Dess et al. (1997), we also introduced this variable into the analysis. We calculated a second regression equation using 
the interaction terms and evaluated the change in R-square. Table 2 shows the descriptive statistics and correlations of the variables introduced in the regression models.

$<$ Table 2 about here>

As model 1 in Table 3 indicates, strategic renewal is positively and directly related to performance (coef. .362; $p<$ 0.001). Therefore, we can conclude that strategic renewal positively affects firm performance. This first model also shows a direct, positive, and significant effect of cooperation activities on performance (coef. .211; $p<0.001$ ). Moreover, larger firms and those located in high-technology industries appear to have higher levels of performance (coef. .056 and .247, respectively).

\section{$<$ Table 3 about here $>$}

$\mathrm{H}_{1}$ examines the indirect impact of strategic renewal on performance, with the moderation of cooperation. Model 2 in Table 3 presents the results of the moderated hierarchical regression analysis for the hypothesized interactive effect on performance. The effect of the interaction term "cooperation $\times$ strategic renewal" is negative. Contrary to what we predicted, the interaction effects between cooperation and strategic renewal on firm performance are negative and statistically significant (coef. -.070; $p<0.001$ ). Cooperation negatively moderates the relationship between strategic renewal and performance. Among firms with a strong emphasis on strategic renewal, the use of cooperation has a weaker effect on performance (see Figure 2). The values of high and low strategic renewal and cooperation in Figure 2 reflect a standard deviation above and below the mean, respectively. We can graphically observe that the marginal effect of strategic renewal on performance, measured by the slope of the lines, is stronger among firms with lower levels of cooperation. Contrary to our expectations, we find a negative and indirect effect of strategic renewal on performance, with the moderation of cooperation. Therefore, we cannot corroborate $\mathrm{H}_{1}$.

$<$ Figure 2 about here $>$

Finally, $\mathrm{H}_{2}$ measures the interaction effects between the environment's technology intensity and strategic renewal on performance. We find a positive moderated effect of the environment's technological intensity on the renewal-performance relationship. According to these findings, strategic renewal has a stronger positive effect on performance in high-technology-intensive environments than in low- or medium-technology-intensive environments (see Figure 3). The positive, direct effect of strategic renewal on performance (standardized coef. .347; $p<0.001$ ) increases when firms operate in high-technology-intensive environments (standardized coef. .081; $p<0.001$ ). Therefore, we can corroborate $\mathrm{H}_{2}$ and affirm that technological intensity of the environment positively moderates the relationship between strategic renewal and performance. That is, among firms with strong emphasis on strategic renewal, superior performance will occur in environments with high technological intensity. Figure 3 shows the interaction effect graphically. As in Figure 2, high and low strategic renewal categories represent values one standard deviation above and below the mean. As we proposed in $\mathrm{H}_{2}$, the effect of strategic renewal on performance is slightly stronger among firms that operate in high-tech industries than among firms in low- and medium-technology sectors.

\section{$<$ Figure 3 about here $>$}

\section{Discussion}

Statistical research can capture only particular features of complex phenomena, such as the one we investigate in this paper. Using a contingency approach, we have attempted to examine how strategic renewal activities affect performance. We have theoretically discussed how cooperation may benefit specific renewal activities and how these activities have a different impact on different environments. The moderating impact of cooperation and environment on strategic renewal has important implications for managers. The results of this study also provide support for the contingency approach, as models incorporating the moderating effects of cooperation and environment are critical for achieving greater understanding of the complex effects of strategic renewal on performance.

An important finding is the weaker effect of strategic renewal on performance when firms cooperate. Firms tend to cooperate to gain market access and additional opportunities (Hagedoorn, 1993). However, according to our findings, cooperation and strategic renewal do not seem to be a good combination. The implementation of new corporate strategies, new organizational structures, and advanced management techniques seems to directly and positively affect performance measures, whereas there is a weaker impact of strategic renewal on performance when moderated by cooperation. It is possible that strategic renewal requires closer integration and more focused commitment than can be obtained through the cooperation of otherwise independent entities. We posit that this is why its interactive impact on cooperation is negative. An alternative or complementary explanation could be the agency problems that firms face in cooperative relationships. Partners often need to share the outputs of the alliance, and thus the firm does not have exclusive rights to such outputs. This lack of rights increases the difficulty of the firm's renewal efforts, which may not be unique after all. 
Therefore, cooperation could reduce pioneer advantages that could be obtained through strategic renewal. In this vein, Teng (2007) argues that when exclusivity is important for strategic renewal, cooperation is not appropriate.

Inter-organisational cooperative arrangements allow firms to learn new capabilities (Hitt et al., 2000) and use resources from others for their own benefit (Grant \& Baden-Fuller, 2004). However, as mentioned previously, there is a risk in losing distinctive competencies through collaboration because partners can appropriate firm-specific knowledge (Hamel, 1991). Thus, cooperation can hinder first-mover advantages. We also argue that cooperation might slow down the renewal processes as a result of additional coordination efforts. Strategic alliances and other cooperation arrangements need some effort on the part of the companies to fit with and adapt to partners' culture. These coordination costs may slow down the renewal process and negatively affect performance, as we found in our empirical analysis.

This research shows that the moderating impact of the environment's technology intensity is also substantial. Our findings indicate that strategic renewal has a greater influence on performance for firms that operate in high-technology-intensive sectors. The positive impact of strategic renewal on performance is also amplified for these firms. In high-technology-intensive environments, strategic renewal becomes a necessary condition to obtain a competitive advantage. Thus, firms that operate in such sectors (e.g., computer software) must continually innovate and renew to remain competitive.

In summary, the moderating effect of cooperation on performance suggests that strategic renewal activities aimed to increase market share, reduce labour costs, increase capacity, and provide production flexibility have better results when they are undertaken alone (with no cooperation) and in firms that operate in high-technology-intensive industries.

Although our analysis is cross-sectional, the variables pertain to the 1998-2000 period, and thus any causality effects should be considered with caution. Further research should approach this issue from a longitudinal perspective. Longitudinal studies would be able to address causality as well as analyse the relationship among cooperation, strategic renewal activities, and performance more accurately. Cooperation between firms may often arise because they have been more innovative and successful in the past and therefore are considered more attractive partners. Further research should also investigate the different types of cooperation and their effect on the relationship between strategic renewal and performance, as well as the potential contingent effect of other moderating variables, such as industry concentration or firms' business strategy.

\section{References}

Antoncic, B. (2006). Impacts of diversification and corporate entrepreneurship strategy making on growth and profitability: a normative model. Journal of Enterprising Culture, 14 (1), 49-63. http://dx.doi.org/10.1142/S0218495806000040

Arnold, H. J. (1982). Moderator variables: a clarification of conceptual, analytic, and psychometric issues. Organizational Behaviour and Human Performance, 29, 143-174. http://dx.doi.org/10.1016/0030-5073(82)90254-9

Bamberger, P. (2008). Beyond contextualization: using context theories to narrow the micro-macro gap in management research. Academy of Management Journal, 51 (5), 839-846.

Bayona, C., García-Marco, T., \& Huerta, E. (2001). Firm’s motivations for cooperative R\&D: an empirical analysis of Spanish firms. Research Policy, 30, 1289-1307. http://dx.doi.org/10.1016/S0048-7333(00)00151-7

Beer, M., Eisenstat, R., \& Spector, B. (1990). The critical path to corporate renewal. Boston: Harvard University Press.

Chang, Y. C. (2003). Benefits of co-operation on innovative performance: evidence from integrated circuits and biotechnology firms in the UK and Taiwan. R\&D Management, $33 \quad$ (4), $425-437$. http://dx.doi.org/10.1111/1467-9310.00308

Cooper, A. C. (2002). Networks, alliances, and entrepreneurship. In M. A. Hitt, R. D. Ireland, S. M. Camp, \& D. L. Sexton (Eds.). Strategic entrepreneurship: Creating a new mindset (pp. 203-217). Oxford: Blackwell Publishers.

Covin, J., \& Miles, M. (1999). Corporate entrepreneurship and the pursuit of competitive advantage. Entrepreneurship Theory and Practice, 23, 47-63.

Covin, J., \& Slevin, D. P. (1991). A conceptual model of entrepreneurship as firm behaviour. Entrepreneurship Theory and Practice, 16 (1), 7-25.

Deeds, D. L., \& Hill, C. W. L. (1996). Strategic alliances and the rate of new product development: an empirical study of entrepreneurial firms. Journal of Business Venturing, 11, 41-55. http://dx.doi.org/10.1016/0883-9026(95)00087-9 
Dess, G. G., Lumpkin, G. T., \& Covin, J. G. (1997). Entrepreneurial strategy making and firm performance: tests of contingency and configurational models. Strategic Management Journal, 18 (9), 677-695. http://dx.doi.org/10.1002/(SICI)1097-0266(199710)18:9<677::AID-SMJ905>3.0.CO;2-Q

Floyd, S. W., \& Lane, P. J. (2000). Strategizing throughout the organization: managing role conflict in strategic renewl. Academy of Management Review, 25, 154-177.

Grant, R. M., \& Baden-Fuller, C. (2004). A knowledge accessing theory of strategic alliances. Journal of Management Studies, 44 (1), 61-84.

Gulati, R., Nohria, N., \& Zaheer, A. (2000). Strategic networks. Strategic Management Journal, 21 (3), $203-215$. http://dx.doi.org/10.1002/(SICI)1097-0266(200003)21:3<199::AID-SMJ98>3.0.CO;2-0

Guth, W. D., \& Ginsberg, A. (1990). Guest editors' introduction: Corporate entrepreneurship. Strategic Management Journal, 11, 5-15.

Hagedoorn, J. (1993). Understanding the rationale of strategic technology partnering: interorganizational modes of cooperation and sectoral differences. Strategic Management Journal, $14 \quad$ (5), 371-385. http://dx.doi.org/10.1002/smj.4250140505

Hagedoorn, J., \& Sadowski, B. (1999). The transition from strategic technology alliances to mergers and acquisitions: an exploratory study. Journal of Management Studies, 36, 87-107. http://dx.doi.org/10.1111/1467-6486.00127

Hagedoorn, J., \& Schakenraad, J. (1994). The effect of strategic technology alliances on company performance. Strategic Management Journal, 15, 291-309. http://dx.doi.org/10.1002/smj.4250150404

Hamel, G. (1991). Competition for competence and inter-partner learning within international strategic alliances. Strategic Management Journal, 12, 83-103. http://dx.doi.org/10.1002/smj.4250120908

Hart, S. (1992). An integrative framework for strategy-making processes. Academy of Management Review, 17, 327-351.

Hitt, M. A., Ireland, R. D., \& Lee, H. (2000). Technological learning, knowledge management, firm growth and performance. Journal of Engineering, and Technology Management, 17, 231-246. http://dx.doi.org/10.1016/S0923-4748(00)00024-2

Inkpen, A. C. (2000). Learning through joint ventures: a framework of knowledge acquisition. Journal of Management Studies, 37, 1019-1044. http://dx.doi.org/10.1111/1467-6486.00215

Khandwalla, P. N. (1987). Generators of pioneering innovative management: some Indian evidence. Organization Studies, 8 (1), 39-59. http://dx.doi.org/10.1177/017084068700800104

Kim, H.E \&.Pennins J.M.(2009) Innovation and strategic renewal in mature markets: A Study of the tennis racket industry, Organization Science, 20 (2), 368-383. http://dx.doi.org/10.1287/orsc.1080.0420

Kreiser, P., Marino, L., Davis, J., Tang, Z. \& Lee, C. (2010) Firm-level entrepreneurship: The role of proactiveness innovativeness and strategic renewal in the creation and exploration of opportunities,.Journal of Developmental Entrepreneurship, Vol. 15 (2), 143-163, http://dx.doi.org/10.1142/S1084946710001488

Kwee, Z.; Bosch, F.; Volberda, H. W.(2011) The influence of top management team's corporate governance orientation on strategic renewal trajectories: A longitudinal analysis of Royal Dutch Shell plc, 1907-2004 Journal of Management Studies, 48 (5), 984-1014, http://dx.doi.org/10.1111/j.1467-6486.2010.00961.x

Lee, C., Lee, K., \& Pennings, J. M. (2001). Internal capabilities, external networks, and performance: a study on technology-based ventures. Strategic Management Journal, 22, 615-640. http://dx.doi.org/10.1002/smj.181

Liberman, M. B., \& Montgomery, D. B. (1988). First-mover advantage. Strategic Management Journal, 9, 41-58. http://dx.doi.org/10.1002/smj.4250090706

Miller, D., \& Friesen, P. H. (1982). Innovation in conservative and entrepreneurial firms: two models of strategic momentum. Strategic Management Journal, 3, 1-25. http://dx.doi.org/10.1002/smj.4250030102

Miller, D., Droge, C., \& Toulouse, J. (1988). Strategic process and content as mediators between organizational context and structure. Academy of Management Journal, 31, 544-569.

Mody, A. (1993). Learning through alliances. Journal of Economic Behaviour and Organization, 20, 151-170. http://dx.doi.org/10.1016/0167-2681(93)90088-7

Naman, J. L., \& Slevin, D. P. (1993). Entrepreneurship and the concept of fit: A model and empirical tests. Strategic Management Journal, 14 (2), 137-153. http://dx.doi.org/10.1002/smj.4250140205 
Neter, J., Kunter, M. H., Nachtsheim, C. J., \& Wasserman, W. (1996). Applied linear statistical models, (4th ed.). Chicago: Richard D. Irwin.

OECD (2005). Proposed guidelines for collecting and interpreting technological innovation data. Oslo: OECD. http://dx.doi.org/10.1787/9789264013100-en

Sarkar, M. B., Echambadi, R. A. J., \& Harrison, J. S. (2001). Alliance entrepreneurship and firm market performance. Strategic Management Journal, 22, 701-711. http://dx.doi.org/10.1002/smj.179

Sharma, P., \& Chrisman, J. J. (1999). Toward a reconciliation of the definitional issues in the field of corporate entrepreneurship. Entrepreneurship Theory and Practice, 23, 11-27.

Smith, K. G., Carroll, S. J., \& Ashford, S. J. (1995). Intra- and interorganizational cooperation: toward a research agenda. Academy of Management Journal, 38 (1), 7-23.

Stopford, J. M., \& Baden-Fuller, C. W. F. (1990).Corporate rejuvenation. Journal of Management Studies, 27 (4), 399-415. http://dx.doi.org/10.1111/j.1467-6486.1990.tb00254.x

Teng, B. (2007). Corporate entrepreneurship activities through strategic alliances: a resource-based view approach toward competitive advantage. Journal of Management Studies, $33 \quad$ (1), 119-142. http://dx.doi.org/10.1111/j.1467-6486.2006.00645

Teng, B., \& Cummings, J. L. (2002). Trade-offs in managing resources and capabilities. Academy of Management Executive, 16, 81-91.

Van Driel, H. (1992). Co-operation in the Dutch container transport industry. Service Industry Journal, 12 (4), $512-532$. http://dx.doi.org/10.1080/02642069200000062

Verbeke, A., Chrisman, J. J., \& Wenlong, Y. (2007). A note on strategic renewal and corporate 31, venturing in the subsidiaries of multinational enterprises. Entrepreneurship, Theory and Practice, 31 (4), 585-600. http://dx.doi.org/10.1111/j.1540-6520.2007.00189.x

Veugelers, R., \& Cassiman, B. (2005). R\&D cooperation between firms and universities: some empirical evidence from Belgium. International Journal of Industrial Organization, 23 (5-6), 355-379. http://dx.doi.org/10.1016/j.ijindorg.2005.01.008

Wiklund, J. (1999). The sustainability of the entrepreneurial orientation-performance relationship. Entrepreneurship Theory and Practice, 24, 37-48.

Yoshino, M. Y., \& Rangan, U. S. (1995). Strategic alliances: an entrepreneurial approach to globalisation. Boston: Harvard Business School Press.

Zahra, S. A. (1993). Environment, corporate entrepreneurship and financial performance: a taxonomic approach. Journal of Business Venturing, 8, 319-340. http://dx.doi.org/10.1016/0883-9026(93)90003-N

Zahra, S. A. (1995). Corporate entrepreneurship and company performance: the case of management leveraged buyouts. Journal of Business Venturing, 10, 225-247. http://dx.doi.org/10.1016/0883-9026(94)00024-O

Zahra, S. A. (1996). Governance, ownership, and corporate entrepreneurship: the moderating impact of industry technological opportunities. Academy of Management Journal, 39, 1713-1735

Zahra, S. A., Jennings, D. F., \& Kuratko, D. F. (1999). The antecedents and consequences of firm-level entrepreneurship: the state of the field. Entrepreneurship Theory and Practice, 24, 45-65.

\section{Notes}

Note 1. The Spanish survey (CIS3) defines innovation as either a new or significantly improved product (goods or service) introduced into the market (product or service innovation) or the introduction within the firm of a new or significantly improved process (process innovation).

Note 2. Each variable takes the value 0 when the firm does not cooperate, 1 when importance of cooperation is low, 2 when importance of cooperation is medium, and 3 when importance of cooperation is high. 
Table 1. Variable definition and reliability analysis

\begin{tabular}{|c|c|c|c|}
\hline Construct & Research variables & $\begin{array}{c}\text { Cronbach's } \\
\text { Alpha }\end{array}$ & $\begin{array}{c}\text { Exploratory factor } \\
\text { analysis } \\
\text { Factor loadings }\end{array}$ \\
\hline Performance & $\begin{array}{l}\text { Reduced unit labour costs } \\
\text { Improved production flexibility } \\
\text { Reduced materials and/or energy per produced unit } \\
\text { Met regulations or standards } \\
\text { Improved quality of goods or services } \\
\text { Improved environmental impact or health and safety aspects }\end{array}$ & .923 & $\begin{array}{c}.881 \\
.868 \\
.861 \\
.851 \\
.840 \\
.836 \\
\text { Eigenvalue: } 4.400 \\
\text { Var .explained: } \\
\text { 73.336 }\end{array}$ \\
\hline $\begin{array}{c}\text { Strategic } \\
\text { renewal }\end{array}$ & $\begin{array}{l}\text { Implementation of new or significantly changed corporate } \\
\text { strategies } \\
\text { Implementation of new or significantly changed } \\
\text { organisational structures } \\
\text { Changing significantly your firm's marketing } \\
\text { concepts/strategies } \\
\text { Implementation of advanced management techniques within } \\
\text { your firm }\end{array}$ & .790 & $\begin{array}{l}.800 \\
.812 \\
.729 \\
.791 \\
\text { Eigenvalue: } 2.45 \\
\text { Var .explained: } \\
61.38\end{array}$ \\
\hline Cooperation & $\begin{array}{l}\text { Importance of cooperation in entrepreneurial activities with } \\
\text { clients } \\
\text { Importance of cooperation in entrepreneurial activities with } \\
\text { Universities } \\
\text { Importance of cooperation in entrepreneurial activities with } \\
\text { research centres } \\
\text { Importance of cooperation in entrepreneurial activities with } \\
\text { suppliers } \\
\text { Importance of cooperation in entrepreneurial activities with } \\
\text { experts } \\
\text { Importance of cooperation in entrepreneurial activities with } \\
\text { R\&D firms } \\
\text { Importance of cooperation in entrepreneurial activities with } \\
\text { competitors } \\
\text { Importance of cooperation in entrepreneurial activities with } \\
\text { group members }\end{array}$ & .862 & $\begin{array}{c}.759 \\
.776 \\
.749 \\
.741 \\
.702 \\
.700 \\
.652 \\
.652 \\
\text { Eigenvalue: } 4.122 \\
\text { Var. explained: } \\
\text { 51.52 }\end{array}$ \\
\hline
\end{tabular}


Table 2. Descriptive statistics and correlation table

\begin{tabular}{|l|c|c|c|c|c|c|c|}
\hline \multicolumn{1}{|c|}{ Variable } & Mean & $\begin{array}{c}\text { Standard } \\
\text { Deviation }\end{array}$ & 1 & 2 & 3 & 4 & 5 \\
\hline Performance & 0 & 1 & 1 & & & & \\
\hline Size & 4.672 & 0.708 & .155 & 1 & & & \\
\hline High-tech industry & 0.177 & 0.382 & .201 & .077 & 1 & & \\
\hline Strategic renewal & 0 & 1 & .415 & .211 & .117 & 1 & \\
\hline Cooperation & 0 & 1 & .327 & .164 & .191 & .201 & 1 \\
\hline
\end{tabular}

Note. We obtained the performance, strategic renewal, and cooperation variables in the previous analysis. They have a mean of 0 and standard deviation of 1 .

Table 3. Moderated hierarchical regression analysis

\begin{tabular}{|l|r|r|}
\hline & \multicolumn{2}{|c|}{ Dependent variable: Performance } \\
\hline Independent variables & Model 1 & \multicolumn{1}{|c|}{ Model 2} \\
Moderated \\
Intercept & Direct & Effects \\
\hline Size & Effects & $-.277^{*}$ \\
& $(-5.037)$ \\
High-tech industry & $(-5.517)$ & $.053^{*}$ \\
& $.056^{*}$ & $(4.540)$ \\
Strategic renewal & $(4.772)$ & $.229^{*}$ \\
Cooperation & $.247^{*}$ & $(10.523)$ \\
& $(11.493)$ & $.347^{*}$ \\
Cooperation $\times$ strategic renewal & $.362^{*}$ & $(37.668)$ \\
High-tech $\times$ strategic renewal & $(43.356)$ & $.274^{*}$ \\
& $.211^{*}$ & $(24.137)$ \\
Change in $\mathrm{R}^{2}$ & $(25.209)$ & $-.070^{*}$ \\
Adj. $\mathrm{R}^{2}$ & & $(-8.544)$ \\
& & $.081^{*}$ \\
& & $(3.906)$ \\
\hline
\end{tabular}

*sig. 99\% (t-values are in parentheses). 


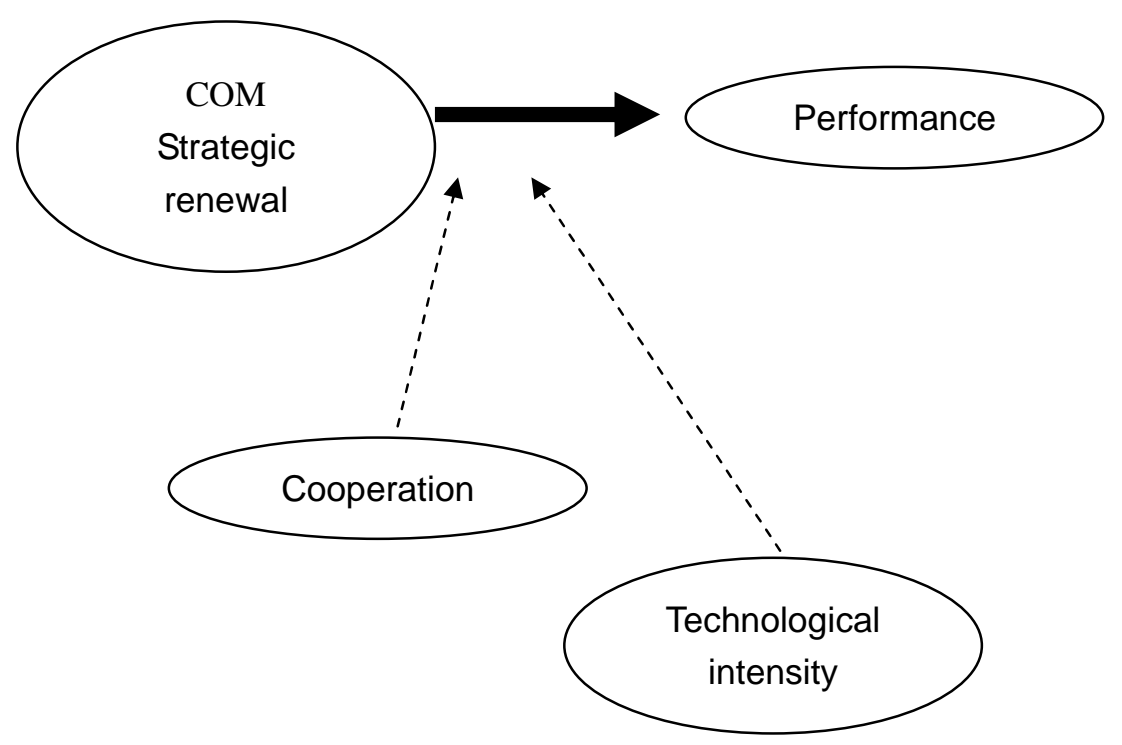

Figure 1. Model 


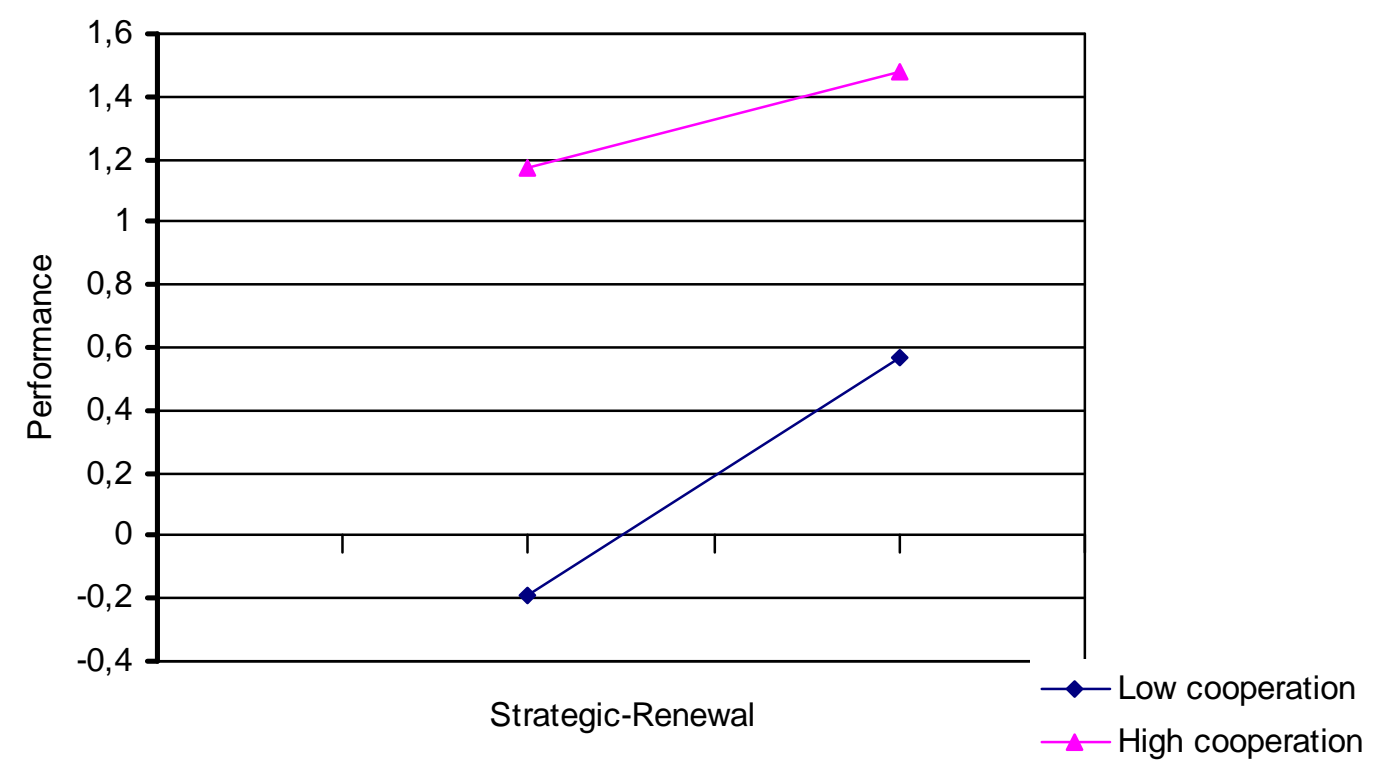

Figure 2. Cooperation as a Moderator of the Strategic Renewal-Performance Relationship

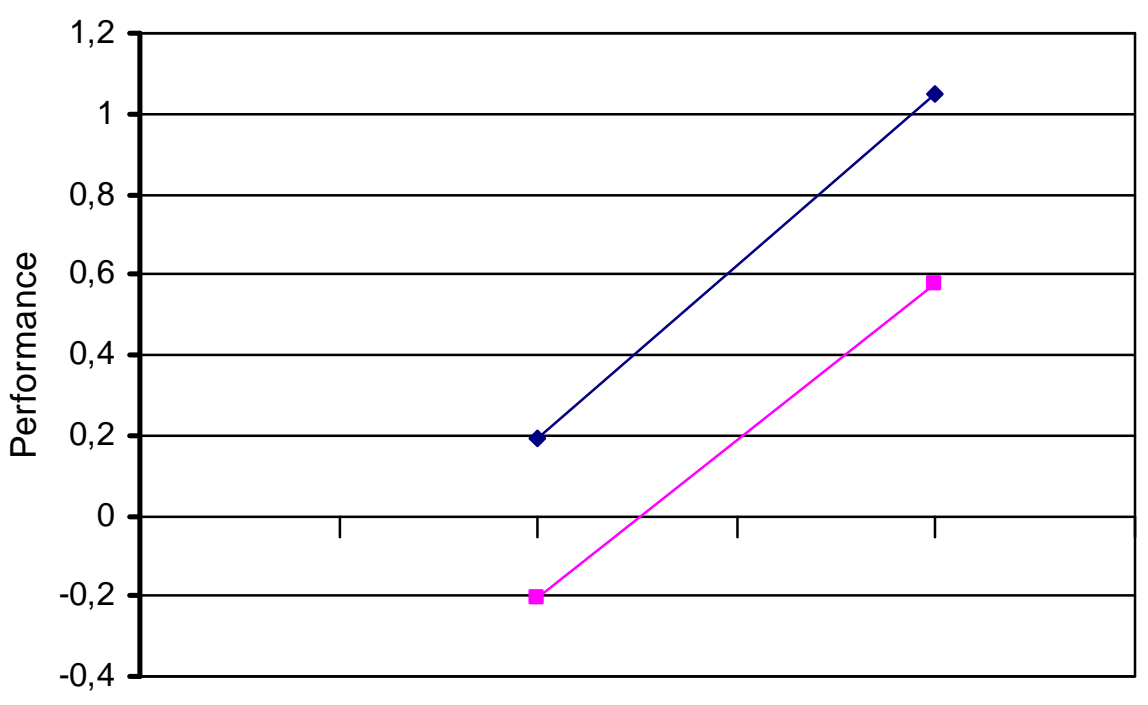

Strategic-renewal

Figure 3: Environment as a Moderator of the Strategic Renewal-Performance Relationship 